\title{
A Reply to Critics of Constitutional Goods
}

\author{
Alan Brudner \\ Version Publisher's Version \\ Citation Alan Brudner, "The Liberal Duty to Recognize Cultures" (2003) 8:2 \\ (published version) Review of Constitutional Studies 129-168.
}

Publisher's Statement This article has been reproduced with the permission of Oxford University Press. The final publication is available at https://doi.org/10.1093/acprof:oso/9780199225798.003.0011

How to cite TSpace items

Always cite the published version, so the author(s) will receive recognition through services that track citation counts, e.g. Scopus. If you need to cite the page number of the author manuscript from TSpace because you cannot access the published version, then cite the TSpace version in addition to the published version using the permanent URI (handle) found on the record page.

This article was made openly accessible by $U$ of $T$ Faculty. Please tell us how this access benefits you. Your story matters. 


\section{The Liberal DUTY TO ReCognize Cultures}

\begin{abstract}
Alan Brudner
The author argues that the dissonance between a liberal constitutional order and the recognition of diverse cultural communities is surmountable. He argues that there is a way of legitimating the application of liberal constitutional norms to non-liberal cultures provided that one assumes that all self-reproducing cultures are equally good. One can then reconcile the liberal duty to recognize cultures with constraints on cultural practices that are non-threatening.
\end{abstract}

\begin{abstract}
L'auteur fait valoir qu'il est possible de surmonter la dissonance entre l'ordonnance constitutionnelle libérale et la reconnaissance de diverses communautés culturelles. Il fait valoir qu'il existe une manière de rendre légitime l'application de normes constitutionnelles libérales à des cultures non libérales dans la mesure où l'on accepte au même titre toutes les cultures autoreproductrices. On peut alors concilier le droit libéral de reconnaître les cultures et les contraintes non menaçantes de pratiques culturelles.
\end{abstract}

\section{INTRODUCTION}

Most who have thought about the matter agree that the question regarding the place of cultural communities in a liberal constitutional order is, at this stage of the latter's development, the most pressing and troublesome in constitutional theory. The problem's urgency comes from its defining what is perhaps the last frontier for liberal constitutionalism, the line at which liberalism must legitimate not only political authority but also its ways of legitimating authority to people with other ways of doing so. It is safe to say that the nearly unanimous view of people who write on this subject is that this task is impossible and that liberalism must therefore either assert its core principles against non-liberal cultures in the absence of a non-partisan justification or accept the implications of its partisan character and reform its constitution along pluralist lines. ${ }^{1}$

Either path carries implications productive of extreme dissonance in the liberal conscience. The first betrays liberalism's own principle of rational selfimposability as the criterion for valid authority and reveals its allegiance to public reason as the ideological pretense of an imperial power. The second

\footnotetext{
* Albert Abel Professor of Law, University of Toronto.

1 For representative statements of these alternative positions, see Brian Barry, Culture and Equality (Cambridge: Polity Press, 2001) [Culture and Equality]; James Tully, Strange Multiplicity: Constitutionalism in an Age of Diversity (Cambridge: Cambridge University Press, 1995).
}

2003

Revue d'études constitutionnelles 
involves giving up on the idea of a common citizenship and abandoning adherents of non-liberal cultures to practices that may be inconsistent with the equal moral worth of individuals. Much recent literature on cultural diversity consists of proposed strategies for managing this dissonance, accepting its inevitability. Kymlicka, for example, deals with liberalism's cultural dilemma by equivocating on the authority of liberal constitutional norms, allowing them to define the scope of the official duty to support cultural communities (structure but not character) but shying at their enforcement against the illiberal cultural practices of the communities receiving support. ${ }^{2}$ Carens proposes a case-by-case strategy whereby liberalism would even-handedly accommodate cultural differences on matters concerning which neutral respect for freedom of choice is indifferent, but has nothing to say about how to reconcile aloof neutrality with even-handed support or about how to justify enforcing liberalism's bottom line principles (which he views as culturally specific) to the non-liberal cultures whose practices conflict with them (Carens would enforce them whenever "we feel we ought to"). ${ }^{3}$ Shachar, meanwhile, opts for a market solution. She would turn dissonance to advantage by giving the state and religious communities coordinate jurisdiction in contested areas and by making them compete for the loyalty of their jurisdiction-shopping subjects in a kind of multicultural bazaar of legal regimes. ${ }^{4}$ All of these writers try to steer their way between a violent cross-cultural imposition of Western norms and a non-violent but morally toothless cultural pluralism. None, however, thinks that this conflict can be conceptually overcome.

In this article I harness a group of concepts (living ethos, ethical life, the selfsufficient life, the reconciliation story) to the task of overcoming liberalism's dissonance with respect to cultures. I argue that there is indeed a way of legitimating the application of liberal constitutional norms to participants of nonliberal cultures provided that these agents grant one very weak assumption: that all self-reproducing cultures are equally good. This assumption is weak because it seems on its face to argue against liberalism's authority rather than to presuppose it and because cultural pluralists (Walzer, for example) themselves

2 Will Kymlicka, Multicultural Citizenship (Oxford: Clarendon Press, 1995) at 164-70 [Multicultural Citizenship].

3 Joseph Carens, Culture, Citizenship, and Community: A Contextual Exploration of Justice as Even-Handedness (Oxford: Oxford University Press, 2000) at 14, 47.

4 Ayelet Shachar, Multicultural Jurisdictions (Cambridge: Cambridge University Press, 2001) c. 6 [Multicultural Jurisdictions].

Vol. 8 , No. 2

Review of Constitutional Studies 
make this claim when they dispute the legitimacy of that authority. ${ }^{5}$ Once this assumption is granted, I argue, we can show how a liberal duty to recognize cultural diversity can be combined with strong constraints on cultural practices that do not appear to non-liberal cultures as the alien impositions of an occupying power.

We should be clear at the outset about what this task demands of us. It does not demand that we justify liberal norms to each and every culture, taken one by one, showing how each could accept those norms from the standpoint of its own core beliefs. Such a task would be foredoomed to failure (who are we liberals to decide what beliefs are central to a foreign culture?) and, what is more, unnecessary. We do not think that the authority of the law against murder is undermined just because the murderer believes he has the right to kill whenever killing would further his ends. If the subjective point of view, whether of an individual or a culture, had to be accommodated by a justification of authority, there could be no authority. In fact, however, the addressees of our justification are not cultural anarchists, for they believe that nations owe each other a duty to respect cultural autonomy and thus also a duty to tolerate foreign customs they find repugnant. They believe in this duty because they think there is something about living cultures that makes them all equally worthy of respect and concern; indeed, this is why they wonder why liberal norms should apply to non-liberal cultures. Our task, then, is to justify the application of liberal constitutional norms to people who, while adhering to a non-liberal ethos, also hold the view that all living ethoi are good.

\section{CULTURE IN LIBERTARIANIEGALITARIAN PUBLIC REASON}

The problem of this essay can also be framed as one concerning the possibility of mutual recognition between ostensible opposites. How can the liberal state defer to and promote the distinct ways of parochial cultural communities without surrendering the authority of liberal public reason? How can cultural communities recognize the authority of liberal public reason without surrendering their independence as normative frameworks in their own right? Put that way, the difficulty of finding a place in public order for cultural communities is part of a much larger problem. It is the problem of laying down legal-institutional conditions for the mutual recognition of Law and Law's subjects such that Law's rule is validated by the assent of morally independent

5 Michael Walzer, Spheres of Justice: A Defense of Pluralism and Equality (New York: Basic Books, 1983) at 314.

2003

Revue d'études constitutionnelles 
individuals whose particular interests are reciprocally valued by public authority. I shall call progress toward this goal the reconciliation story.

Liberalism in its familiar variants has been unable to offer a complete answer to the challenge posed to the legitimacy of its state by traditional cultures. Consider first libertarianism. By libertarianism I do not mean the ideology of the minimal state that often goes by that name. Rather, I mean to refer to what Rawls called "the system of natural liberty." Libertarianism in this sense (one might also call it classical liberalism) denotes a constitution governed by a conception of public reason according to which the latter consists in mutual respect for the most extensive individual liberty compatible with equal liberty and nothing else. That conception of public reason is quite compatible with regulation going beyond that of the "nightwatchman state" provided that the regulation's purpose is to secure the infrastructural conditions of ordered liberty, among which one may count the cohesion of the polity around values (e.g. self-reliance, tolerance) supportive of the libertarian constitution. Of course, libertarian public reason is hostile to regulation for the purpose of equalizing anything but liberty starting-points or resources, for example.

Understood as a conception of public reason narrowly focussed on liberty, libertarianism accords no place in the public realm for cultural communities, no more than it does for religion. True, it protects the individual's freedom to espouse the final ends of his choice and to form, join, or leave associations of shared belief; and it reduces the costs to the individual of minority group membership by prohibiting legal fetters on occupational mobility and acquisition based on ascriptive characteristics. These are not negligible helps to minority cultures, as the immigrants who fled regimes ordered to racial or cultural dominance will readily attest. Indeed, they go some way toward laying down objective conditions for inculcating in minority group members a loyalty to the liberal constitution. Still, libertarianism finds itself severely constrained in this respect; for its neutrality regarding final ends requires it to remain aloof from the struggle for survival among cultural communities and thus to leave to their fate minority cultures vulnerable to assimilationist pressures. For libertarian public reason, cultural ways of life are subjective individual choices, the support or protection of which by government must fragment public reason into sectarian rule. It is unfair that liberty be restrained for the particular benefit of a group of like-minded individuals or that some be forced to subsidize the life-style choices of others. Because libertarian public reason is impartial toward these choices, cultural communities must be viewed as private associations toward whose ends

6 John Rawls, A Theory of Justice (Cambridge: Belknap Press, 1971) at 65-72.

Vol. 8, No. 2

Review of Constitutional Studies 
government must assume a posture of benign indifference, allowing them to flourish or wither as their adherents choose. ${ }^{7}$

Describing the indifference as benign, however, leaves an incomplete picture for reasons thoroughly discussed by others. ${ }^{8}$ We have to distinguish, as Carens reminds us, between libertarianism as a pure conception of public reason and the diverse national histories and cultures in which that conception is particularized. ${ }^{9}$ There are different ways (for example, parliamentary and congressional ways, the way of parliamentary sovereignty and the way of judicial review) of specifying the libertarian constitution, and there are still more ways of realizing these models in the language and manners of everyday life. Libertarian indifference is not benign, first of all, because it means allowing the myriad, subtle forces by which the language and manners of large majorities tend to overwhelm those of minorities to have their way. Furthermore, governments that rule under the libertarian conception of public reason cannot be neutral as between the dispositions and attitudes needed to sustain that conception's rule and those of cultural communities inimical to it. Educating the citizen of a libertarian state may erode certain habits of mind of cultural communities together with the customs nurtured by them; and if libertarianism is perceived as itself a particular ethos in relation to those communities, this process will appear assimilationist. Libertarian indifference is not benign, finally, because, when taken as the constitution's fundamental theory, libertarianism acquiesces in the conscious assimilationist policies of dominant cultural groups. This is so because its rationale for protecting the fundamental freedoms against ordinary regulation - that their exercise can be conceived without the necessity of conceiving unconsented-to impingements on others' liberty - applies to belief but not to action living out belief. Action falls into general liberty, whose rationally structured regulation by the state needs no special justification. ${ }^{10}$ For this reason, libertarianism has nothing to say against government's facially neutral insensitivity toward minority cultures in, for example, requiring Sikhs and Jews to conform to the dress codes of the police and military, in forbidding (as part of a general narcotics law) the use of peyote in a tribal religious rite, ${ }^{11}$

7 This posture was, according to Nathan Glazer, part of the American pattern of ethnic disestablishment crystallized in the Civil Rights Act and Voting Rights Act of the 1960s and displaced by the affirmative action programs of the 1970s; see N. Glazer, Affirmative Discrimination: Ethnic Inequality and Public Policy (New York: Basic Books, 1975) at 25-32.

8 See e.g. Multicultural Citizenship, supra note 2 at $110 \mathrm{ff}$.

9 Carens, supra note 3 at $9-11$.

10 See Oregon v. Smith, 494 U.S. 872 (1990).

11 Ibid.

2003

Revue d'études constitutionnelles 
or in making full citizenship for aboriginals conditional on their abandoning traditional ways and identities, leaving it for them to choose. None of these policies attempts to coerce the inward conscience or to curb freedom of speech or association, and so none violates the libertarian constitution. Because libertarian public reason (taken as fundamental) acquiesces in attempts to submerge cultural particularity, the individual Sikh, Jew, Cree, etc. must see in that self-proclaimed public reason a foreign power allied to the power of the dominant culture.

Egalitarian public reason is much more accommodating to cultural communities (and therefore much more inspiring of loyalty in its culturally diverse subjects), but for reasons that have little to do with their intrinsic worth. By egalitarian public reason I mean the model of liberal justice depicted in the theoretical systems of Rawls and Dworkin and whose implications for liberalism's interaction with cultures have been explored in the pioneering work of Kymlicka. ${ }^{12}$ So understood, egalitarianism's principal contribution to the reconciliation story is to make the individual's moral autonomy - including self-authorship and self-rule - rather than mere formal liberty the end of public power. The egalitarian right to self-rule is a right to equal participation in the rule-making and adjudicative functions of government; that of self-authorship is a right to the conditions and opportunities for living a life shaped in accordance with self-endorsed ends. The right of self-authorship entails enhanced, albeit still indirect, support of cultural communities, because it is a right against not only legal but also private discrimination; and it is a right against discrimination based not only on ascriptive characteristics but also on group affiliation and on creed. Thus, the costs of cultural membership to one's life-ambitions are greatly reduced. Moreover, in dissolving — again for reasons of self-authorship - the dichotomy between belief and action, the egalitarian protection for freedom of conscience now requires exemptions from general laws on the basis of conscientious conviction where this can be done without frustrating public goals. So Sikhs can wear their turbans in the police force, Mennonites can educate their children at home, and First Nations can become Canadians without ceasing to be First Nations thanks to the egalitarian principle of neutral concern for self-authorship. ${ }^{13}$ Most importantly, however, egalitarian

Multicultural Citizenship, supra note 2.

13 See Yoder v. Wisconsin, 406 U.S. 205 (1972). Brian Barry denies that exemptions for conscientious belief are required by egalitarian justice, but that is because he places preferences and convictions "in the same boat" and regards the latter as a form of expensive taste. See Culture and Equality, supra note 1 at 36, 40. If the fundamental egalitarian principle is that there is a public duty of equal concern for leading autonomous lives, then

Vol. 8, No. 2

Review of Constitutional Studies 
liberalism is committed to equalizing everyone's chances of leading a selfauthored life and so to providing everyone with the necessary means of doing so. Eventually, egalitarian thought comes to realize that cultural communities are as necessary to self-authorship as a guaranteed basic income, health care, and the fundamental freedoms, because they provide moral frameworks ordered to final ends from which autonomous individuals can choose their moral identities and without which they would be at a loss to do so. ${ }^{14}$ With this discovery, egalitarianism has found a public reason for actively supporting vulnerable cultural communities through a variety of means (which will vary depending on whether the community is indigenous or immigrant) and for limiting the liberty and property rights of others in order to do so. Conversely, cultural communities have a much reinforced reason for submitting to the liberal order as to that which respects their internal integrity and supports their continued existence.

As important as these advances are to the reconciliation story, however, they leave much unaccomplished. Egalitarianism recognizes cultural communities for its own individualistic reasons. It is the right to the full and free exercise of moral conscience that generates exemptions from general laws as well as rights to public resources and (for indigenous groups) self-government for the support of communities of belief considered as "context[s] of choice."15 This focus, however, places severe limits on the extent to which liberal public reason can defer to the internal norms and practices of these communities and thus on the extent to which cultural communities can reciprocally defer to liberal public reason as the support of such practices. We can identify three specific difficulties.

First, because the moral autonomy of the individual is the fundamental norm of the egalitarian constitution, the latter will not permit governments to enact laws whose purpose is to instruct citizens in the well-ordered integration of human goods into a self-sufficient life. By a self-sufficient life I mean a life

exemptions for conscientious belief are required by equal concern, not (as Barry thinks) violations of it. That laws must be general in application presupposes that all choices reflect preferences, accommodations to which unfairly limit the liberty of others. But this view belongs to libertarianism, not to egalitarian liberalism. People may be expected to renounce preferences; but if self-authorship is the end of law, they cannot be expected to renounce profoundly held beliefs.

14 Will Kymlicka, Liberalism, Community, and Culture (Oxford: Clarendon Press, 1989) c. 8 [Liberalism, Community, and Culture]; see also Multicultural Citizenship, supra note 2 at 82-93; Patrick Macklem, Indigenous Difference and the Constitution of Canada (Toronto: University of Toronto Press, 2001) at 71-72.

15 Liberalism, Community, and Culture, ibid. at 166.

2003

Revue d'études constitutionnelles 
lacking in nothing of what is needed for the enjoyment of individual dignity. So, for example, egalitarianism has no theoretical resources for limiting conscientious expression that treats race or culture as self-sufficient communities and that, for the sake of preserving them against real or imagined enemies, promotes hatred toward other races or cultures. In particular, egalitarianism is hamstrung in a case like $R$.. v. Keegstra ${ }^{16}$ where, in the name of neutral concern for self-authorship, egalitarianism will uphold the freedom of anti-Semitic speech, for it knows no public good by which the freedom to express subjective conceptions of the good can be limited. ${ }^{17}$ No doubt, egalitarianism can support restrictions on general liberty to support contexts of moral choice; but it cannot justify restrictions on some individuals' freedom of conscientious expression for the benefit of others', for this freedom is its fundamental common end. Thus, if libertarianism acquiesces in public policies of cultural assimilation, egalitarianism condones racist and xenophobic propaganda by private individuals and groups voicing their conceptions of the good. "Condones" is not too strong a word here. "Tolerates" is too weak, for one can only tolerate that of which one disapproves, and egalitarianism has no resources in public reason with which to disapprove of privately held non-egalitarian beliefs or their expression. No doubt, egalitarian public reason requires the individual with egalitarian beliefs to tolerate the non-egalitarian beliefs and speech of racists, just as it requires the racist to tolerate the non-violent expression of egalitarian beliefs. Because, however, egalitarian public reason is neutral toward beliefs, its state can itself be neither tolerant nor intolerant of the racist beliefs of private individuals or groups. Insofar as the egalitarian state considers racist beliefs to be on a par with egalitarian ones, it may be said to condone them as a valid scheme of ends for individuals.

Second, because egalitarian public reason supports cultural communities only as arrays of options from which to choose life-plans, it ultimately fails to justify public support for any particular community unless preserving that community would be in everyone's interest. If all that is needed is a context for choice, then this can be provided by fostering a rich and varied public culture; it does not require the support of endangered parochial ones. Realistically, of course, most people are not culturally mobile in a way that would make this a sensible strategy. But this is either a superficial and contingent fact about individual psychology or a deep, ontological one about the essential embeddedness of agency in a cultural tradition. If it is the former, then egalitarian support for vulnerable communities is itself superficially contingent on the persistence of a

[1990] 3 S.C.R. 697.

17 Ronald Dworkin, Freedom 's Law (Cambridge: Harvard University Press, 1996) at 214-26.

Vol. 8, No. 2

Review of Constitutional Studies 
human dependence that the increasing homogenization of culture may very well remove; if the latter, then the individual's cultural immobility undercuts the egalitarian picture of the individual as a sovereign chooser of his or her moral identity who needs culture only in the way that someone dining out needs a menu. ${ }^{18}$

Will Kymlicka has a rejoinder to the latter criticism. He argues that moral agents are indeed deeply bound to their cultures, but not in a way that contradicts the liberal egalitarian conception of the autonomous person. This is so because agents are deeply bound only to the culture's structure - to its language and history - but not, as communitarians hold, to the particular content or character of its beliefs. ${ }^{19}$ The content can always be made an object of self-distancing reflection and criticism and so is always subject to revision. However, even were this dichotomy between structure and content tenable (and I shall argue in a moment that it is not), it seems implausible that agents should be deeply connected to the thinnest layer of their culture and superficially connected to the thickest. Even if one rejects a view of language as a mere instrument brought externally to the thoughts it communicates, it seems nonetheless true that language is the formal part of a cultural ethos, the medium by which thoughts are shaped into communicable ideas and transmitted from one generation to the next. Someone who is still able to speak the language of his culture but who is otherwise alienated from its traditions is in no different a position with respect to the culture than someone who has learned a foreign language. Such a person cannot be said to be deeply connected to his own culture. On the contrary, he is precisely someone who is ripe for assimilation to the dominant context of choice.

Third, because egalitarianism presupposes atomism (that is, assumes the fixed reality of the self-supporting self, of the self who owes its worth to nothing beyond its own person), it too must treat particular cultural beliefs and practices as contingent and revisable individual choices it would be unfair to subsidize publicly. This is why it must distinguish between the historically contingent content of a culture and its abstract structure - given, according to Kymlicka, by its language and history; and this is why it must confine its support to the cultural structure, leaving the content to evolve in whatever way it does, while at the same time reserving authority to criticize non-egalitarian cultural practices in light of the principle of equal concern for self-authorship that justifies support

18 In Multicultural Citizenship, supra note 2, Kymlicka canvasses all sorts of reasons, both psychological and deep, for cultural immobility, content if there is any reason that will tie his argument down to the support of particular cultures; see 84-93.

19 Ibid.

2003

Revue d'études constitutionnelles 
for the structure as a context of choice. This means, however, that egalitarianism cannot defer to or support the content of any framework of cultural ends, even if the culture recognizes the creative freedom of its members to elaborate it and so has an internal source of self-examination, criticism, and evolution. Egalitarianism will thus demand that cultural contents defer to its norms without any reciprocal deference to the internal practices of genuine forms of ethical life. ${ }^{20}$ But this inequality of respect means that cultural communities must see the authority of the liberal-egalitarian constitution as the external imposition of an alien power.

The dichotomy between cultural structure and content (or "character") produces further difficulties. That dichotomy, after all, is simply an artefact of the egalitarian's need to abstract from particular choices in order to reach public ground; it does not correspond to the distinction between what is truly essential and what is truly accidental about a culture. Some cultural groups are defined by a substantive idea or practice, others by a language. Jews speak many different languages but form a unified religious group because they believe in the unity of God who revealed Himself on Mount Sinai. Christians would not be Christians if they did not believe in and worship the divinity of Jesus. By contrast, Quebecois culture survived the "quiet revolution" because its unity was constituted principally by a common language and by a collective memory of origins. Thus, protecting structure rather than content means protecting cultures whose unifying cement happens to be a language rather than an idea; and it means discriminating against cultures whose history is nothing but the historical unfolding of an idea, while favouring those whose common heritage is something else (for example, a common memory of conquest). Moreover, in the rare cases where a repressive internal practice (such as the denial of freedom of religion) is essential to the culture's structural survival, egalitarianism finds itself paralysed by a choice between two wrongs: cutting off the culture's life-support, thus breaching a public duty to protect cultural membership, or supporting the practice, thereby abetting the violation of some members' rights under the liberal constitution. Kymlicka seeks an escape from this dissonance by claiming that the problem arises, not for ideal theory, but for one that must deal with situations of partial compliance with liberal-egalitarian norms in a non-ideal world, where the harms of intervention and non-intervention can be weighed in the particular case. ${ }^{21}$ But this is unconvincing. The problem of dissonance arises in practice because ideal theory has set the stage for it by abstracting structure from content and conferring a right to the former irrespective of the latter. This in turn comes

This is defined below.

Liberalism, Community, and Culture, supra note 14 at 198-200.

Vol. 8, No. 2

Review of Constitutional Studies 
from treating cultural membership as a right of self-authoring individuals to a context of choice rather than as a right of situated individuals to the substance of their essential worth. If the public duty were to protect only authentic instances of ethical life - that is, living cultures that value the free interpretation of their devotees - the conflict would never arise. Cultures that survive only by repression have no claim to recognition, for their members do not freely certify them as their good.

Accordingly, while the libertarian and egalitarian constitutions are part of the reconciliation story, they are not the whole story. Let us now see how the narrative is advanced when we view cultural communities as examples of ethical life. By ethical life I mean a certain form or structure immanent in living communities, a form we may describe as the mutual recognition of the common and the particular such that each gains reality through the other's deference to it. Thus, a community exemplifies the form of ethical life if the individual's free commitment to a common way of life as to the ground of his or her worth is met by the community's deference to individual autonomy as to the vehicle of its vibrant actualization. ${ }^{22}$ I shall distinguish between two types of ethical life. In one, the common life is an ethos or custom, whose authority participants accept without demanding that the ethos be open to understanding; I'll call this type of ethical life living ethos or the cultural community. In the other, the common life is governed by a public reason accessible to rational insight, and I'll call this type the political community.

\section{CULTURE AS AN INTRINSIC GOOD}

At the egalitarian standpoint cultures are simply life-plan menus from which agents who are complete prior to cultural membership choose their life-orienting values. This picture does violence to the devotee's experience of his culture as something of which he is a vessel and from whose realization through him he derives personal significance. At the standpoint of ethical life, cultures come into view in the way they appeared to Herder and Hegel: as structures of mutual recognition wherein individuals submit to an ethos for the sake of the personal worth they receive by virtue of the ethos's reciprocal deference to individual agency for the sake of its existence and vitality. ${ }^{23}$ By culture I mean the shared

22 Here I adopt both concept and terminology from Hegel; see G.W.F. Hegel, Philosophy of Right, trans. by T.M. Knox (Oxford: Oxford University Press, 1967) at paras. 142-56.

23 Hegel, ibid. at paras. 146-47; F.M. Barnard, ed. \& trans., J.G. Herder on Social and Political Culture (Cambridge: Cambridge University Press, 1969) at 313 [Herder on Social and Political Culture].

2003

Revue d'études constitutionnelles 
ways, speech, wisdom, memory, and self-interpretation (through histories, literature, song, dance, art, etc.) of families that are united in a firm disposition to live by and perpetuate those ways, to transmit the wisdom to the next generation, and to interpret in their daily lives the customs and traditions held in collective memory. Families that are united in this way form a people. Peoples may be indigenous to a territory or immigrant offshoots of a people autochthonous elsewhere. In the former case, they are called nations, in the latter case, ethnic groups. The difference between nations and ethnic groups, while historically relevant to the kinds of policies each has demanded from governments under liberal constitutions, is of no consequence to the strength of their threshold claim to support. ${ }^{24}$ As stable grounds of individual worth, both indigenous and transplanted cultures are equally good in their own right, quite apart from their value as conditions for leading a self-authored life. That is to say, they are intrinsic goods. As such, they no longer stand outside liberal public reason, drawing whatever indirect support the libertarian and egalitarian constitutions may give them through their protecting freedom of choice or through their redressing inequalities in the conditions of self-authorship. Rather, cultures are now fit objects of public concern by liberal governments who rule under a conception of public reason concerned with all relationships in which

24 Indigenous groups typically claim, language, education, and self-government rights, while ethnic groups, whose members are usually more dispersed and have no unique historical connection with the territory they now inhabit, have generally been content with accommodations falling short of self-government. Of course, nothing about this need be fixed in stone, as Sujit Choudhry argues in "National Minorities and Ethnic Immigrants: Liberalism's Political Sociology" (2002) 10 J. Political Philosophy 54. Kymlicka's theory privileges indigenous cultures which, as "societal cultures" rooted in institutional practices and encompassing a full range of human activities, are the contexts of choice he says are necessary to freedom. See Multicultural Citizenship, supra note 2 at 76-80. But as contexts of individual worth, indigenous and ethnic cultures are equally valuable. For an argument that social facts specific to indigenous difference (prior occupancy, prior sovereignty, and treaty formation) justify a unique constitutional relationship between aboriginal people and the state, see Macklem, supra note 14 at c. 3-6. Macklem's argument quite reasonably presupposes an empirical-historical framework within which white European settlers come into contact with an indigenous population for which the settler culture is an alien imposition. By contrast, this essay's argument tries to place the good of cultural difference within an overarching framework of the self-sufficient political community that both grounds and rationally completes the good of culture and that thus need no longer appear alien to those who live by a cultural ethos, even if that ethos is aboriginal and the carriers of other parts of the framework happen to be white; see infra note 57 . Whether this framework can still justify a special constitutional status for indigenous peoples as a matter of principle (as distinct from pragmatic accommodation given special circumstances) is a question I do not consider here.

Vol. 8, No. 2

Review of Constitutional Studies 
claims to individual worth are validated. Accordingly, they attract liberal concern whether or not they are in danger of disappearing.

If liberal governments have a duty of concern for cultures, then cultures have, in a manner of speaking, correlative rights to concern. The idea, however, that cultures can have rights is unintelligible to many liberal writers. Brian Barry, for example, asserts that " [c]ultures are simply not the kind of entity to which rights can properly be ascribed." ${ }^{25}$ Only individual persons are right-bearers, for only individuals can have interests it would be wrong for others to harm or fail to promote. Even were it conceded, moreover, that membership in a cultural community were an important ingredient of individual well-being, it would not follow (some argue) that communities could claim a legal right to concern, for the good of cultural membership might be better promoted through the liberty and anti-discrimination rights enjoyed by individuals. ${ }^{26}$ Others worry that attributing rights to groups would mean eroding the rights of individuals in relation to the group, both that of insiders and outsiders. If cultural groups have rights to the public support and accommodation of their differences, does it not follow that the freedom of outsiders must now be restricted for the particular interests of others or that insiders must lose the protections vis-à-vis group rulers that they otherwise enjoy under the liberal constitution?

The last-mentioned concern is the focus of much of the remainder of this essay. I will suggest how the rights of cultural groups can be integrated with libertarian and egalitarian rights within a political constitution whose authority non-egalitarian cultural groups can recognize. The antipathy toward group rights expressed in the first and second-mentioned objections (that the group as such has no independent interest a right could protect and that any individual interest in group membership can be protected by individual rights) is based on a misunderstanding of the claim to these rights. The claim is not that the group as some reified abstraction is a right-bearer; it is that the individual worth-claim that is validated in cultural life is a fit object for public recognition by a liberal state whose end is the dignity of the individual. Thus, the being for whose sake the right is protected is still the individual, but the individual is now considered, not as a universal person (as he still is in other aspects of life), but as someone for whom membership in a particular cultural group is intrinsically good because a source of realized dignity. This good is inadequately protected by individual

25 Barry, supra note 1 at 67. See also Liberalism, Culture, and Community, supra note 14 at 241-42.

26 See Michael Hartney, "Confusions Concerning Collective Rights” (1991) 4 Can. J. L. \& Jur. 293 at $301-307$.

2003

Revue d'études constitutionnelles 
rights, however, because cultures are worth-conferring only insofar as they are taken as ontological ends requiring individual agents for their realization; and protecting them only through individual rights, as if they were goods wholly servient to individuals, already denies their status as ontological ends. ${ }^{27}$ That said, however, the claim that cultural membership carries rights that governments ought to respect is not so different a claim from that on which libertarian and egalitarian rights rest. The libertarian constitution does not recognize as rights all claims to final worth by the individual; it does not, for example, recognize any claim to lordship over slaves. Rather, it recognizes only those claims to worth that are capable of being recognized by an equal self. That is to say, it recognizes claims to worth validated within a relationship of mutual recognition. Now, if the liberal constitution recognizes the rights emergent from relationships of mutual recognition between putatively self-supporting agents, then a fortiori it should recognize the validated worth claims emergent from relationships in which individuals are intentionally embedded. And one such relationship is that between the agent and the cultural ways with which he or she identifies. When the right of cultures is seen in this light - as the right of individuals to the preservation of the cultural basis of their worth - it is the exclusive focus on isolated persons as right-bearers that becomes unintelligible. Why should rights attach only to individual agents who view themselves as uprooted from relations of mutual recognition?

\section{A. Race, Culture, and Political Community}

We can sharpen the sense in which the term culture is used in this essay by demarcating its borders with neighbouring concepts, so to speak. First, culture is distinguished from race. Because a culture is normally transmitted by the family from one generation to the next, it bears some connection to the race, but that connection is ultimately contingent. We can say that race is to culture what the abstract sexual union is to love, marriage, and the family. If a sexual union

27 As does protecting them with collective rights on the theory that collective interests are individual interests in goods having the special features of public or shared goods; see Leslie Green, "Two Views of Collective Rights" (1991) 4 Can. J. L. \& Jur. 315; Denise Reaume, "Individuals, Groups, and Rights to Public Goods" (1988) 38 U.T.L.J. 1. Here rights are ascribed to collectivities for reasons that fail to capture the sense in which cultural communities are worth-conferring and not simply good in an indeterminate sense. Cultural communities are indeed shared goods, but that is not a sufficient reason to place liberal governments under a duty to promote them. Team sport is also a shared good. Nor is the importance of the interest in the shared good a sufficient reason. Friendship is a shared good important to well-being, but few would think that governments are compelled to foster friendships of all kinds.

Vol. 8 , No. 2 Review of Constitutional Studies 
between two human individuals brings to appearance the biological kind, then a chain of such unions brings to life the race (a species of the kind), which materializes in the common physical features of its members. Moreover, just as the biological kind treats the individual as insignificant, so too does the race. As a member of the race, the individual comes to no special worth, because the race requires nothing of the individual other than that he or she blindly produce offspring through abstract sexual unions. The race does not need to be recognized by the individual in order to exist, and so the individual is unimportant to the race. This is why racial purity is not a constitutional good for liberalism and why it would be an unconstitutional use of power to restrict liberty for its sake, as anti-miscegenation laws do, or to define membership in a politically recognized group exclusively by descent, as the Federal Republic of Germany does. Culture, by contrast, requires commitment for its survival and vitality, and so it is a source of worth for the individual devotee. As such, it, but not the race, can be said to be an ethical end of the individual. This is why Herder argued that cultures and nations form the really salient divisions of the human genus, whereas races tend to be vanishing things. "Complexions run into each other," he wrote, whereas a nation forms a distinct community united by language and culture. ${ }^{28}$ Because recognized commitment to a way of life rather than biological descent defines cultural membership, race comes to have an epiphenomenal significance as a marker or sign of an ethical connection that others must demonstrate more palpably - through a conversion rite, for instance, or simply by adopting the culture's language and manners. True, a race is often the principal carrier of a culture, but cultures can survive intermarriages and immigration, just as marriages can survive the cooling of sexual passion.

If culture is distinguished at its lower border from race, it is distinguished at its upper border from the political community. If culture were the self-sufficient community, if it contained all that is needed for the validation of individual worth, then the political community would be nothing but the nation organized under a central authority for the purpose of protecting and promoting the nation's culture. Political authority would thus be servient to the nation, and every nation would be entitled to political sovereignty. Nationalism is the view that culture is the self-sufficient community. ${ }^{29}$ It is, however, a mistaken view. Culture is not self-sufficient because, claiming authority as custom, it fails to satisfy the autonomous personality who needs to see in what it accepts as normatively valid the specification of some rational principle. From our standpoint, culture is an intrinsic good because it instantiates the mutual recognition structure of ethical

Herder on Social and Political Culture, supra note 23 at 284.

As it was for Herder; see ibid. at 324.

2003

Revue d'études constitutionnelles 
life, and so it is one among many spheres in which individual worth is validated. For the individual immersed in a culture, however, culture claims authority as ethos - as that which is simply given irrespective of content and thus irrespective of its connection with any principle. Thus, while culture affords the individual a feeling of personal significance and is part of what a life of dignity requires, the free mind incipient in culture cannot rest content with it. This means that the political community is not coextensive with the cultural community or with the nation. The political community is the self-sufficient community encompassing all that is needed for a life of individual dignity, including the content of rights and entitlements unfolded from the libertarian and egalitarian conceptions of public reason, and political authority is the agent of this inclusive life. The cultural community is only one aspect thereof. Political communities that encompass a plurality of cultural communities (multicultural polities) under a conception of public reason that protects individual rights, promotes the conditions for equal self-authorship, and fosters common goods, may thus rightly claim to be better exemplars of the liberal constitutional state than nation-states, in which public reason is tainted by ethnic interests. I shall call the public reason organizing the self-sufficient community the inclusive conception.

\section{B. Hate Speech}

Under the egalitarian constitution taken alone, the Canadian Supreme Court's upholding the law under which James Keegstra was convicted for teaching his anti-Semitic beliefs to his pupils appears as a betrayal of liberal principle in the kind of case that puts a liberal's integrity to the test. Not so from the standpoint of the inclusive conception. From the vantage-point that sees liberal goods in social structures conferring individual worth, laws regulating the expression of hate exactly parallel laws regulating pornography. Their purpose, it turns out, is not to prevent offence or indirect physical harm to others; nor is it to protect the self-respect of minority group members. To these ends, the right of selfauthorship through conscientious expression (falling short of incitement to crime) has no reason to bow, for no one may claim protection for his selfexpression at the expense of the rights-respecting self-expression of others. Rather their purpose is to instruct citizens in the self-sufficient life within bounds consistent with the right of self-authorship. Just as obscenity laws teach the integration of sex into love and moral commitment, so do laws against promoting hatred toward groups teach the integration of racial into cultural identity and the integration of cultural identity into citizenship in a political community within which all cultural examples of ethical life are valued. Thus, Justice Dickson came closest to the mark when he said that Canada's hate speech law constituted a reasonable limit to free expression because the fostering of respect among cultural communities is a goal to which the right of free

Vol. 8, No. 2

Review of Constitutional Studies 
expression must defer. He did not say why it must defer, but we can perhaps supply the missing argument.

The egalitarian principle of neutral concern for self-authorship is not the fundamental principle of the liberal constitution. Rather, the principle of neutral concern is part of a larger story about reconciling public authority with individual moral autonomy so that each can submit for validation to acceptance by the other without self-loss. The egalitarian principle contributes to that story by imposing on government a duty of concern for the conditions of selfauthorship that allows public authority to be constructively self-imposed by free and equal citizens. The performance of that duty produces the legal framework of the equal opportunity state that forms part of the objective conditions for inspiring real (not just constructive) loyalty toward public authority as to that which shows equal concern for everyone's accomplishing his or her life-goals. But also part of the reconciliation story are the social structures - marriages, families, nations - that individuals spontaneously form in quest of a stable basis of worth; for these are common goods in the private sphere that public authority can nurture without fragmentation, and this concern will in turn allow private bodies to defer to public authority without loss to their internal autonomy. So the public authority has an interest in fostering these goods. It has an interest in encouraging the complex integration of individual striving into worthconfirming social structures that will make possible the ultimate reconciliation of public authority and individual autonomy in the self-sufficient political community.

Now, when faced with this larger picture, the claims of self-authorship can no longer be advanced abstractly or in isolation. These claims now properly defer to what is needed for the fulfilment of the reconciliation narrative, for the right of autonomy is first solidly established within it. And part of what is needed are laws that show individuals the way to a public life lacking in nothing of what is needed for the enjoyment of their dignity. It is good for individuals that their racial identities be integrated into cultural ones and that their cultural identities be integrated into political citizenship. However, this path cannot be imposed on the individual, or it would not be a path toward reconciling authority and autonomy. Here laws must guide rather than coerce, for they must leave room for the individual's spontaneous endorsement of the self-sufficient community as his good.

2003

Revue d'études constitutionnelles 
The Canadian law on hate propaganda does this by creating several defences to a charge of promoting hatred toward an identifiable group. ${ }^{30}$ First, the law leaves private conversation alone; it is concerned only with statements that communicate a public teaching contrary to the public teaching of the selfsufficient community. Second, it does not punish the communication of any statement that is true. This is not because the dissemination of true facts is of earth-shaking importance but because, if the statement is true, then the speaker very likely knew it to be true; and if he spoke what he knew to be true, the law cannot consistently with respect for self-authorship punish him for his selfexpression. Third, even if the statements were false, the law will not punish the speaker if he spoke on a matter of public interest believing on reasonable grounds that his statements were true. If reasonable grounds are lacking, then he was either lying when he spoke, or willfully deceiving himself, or his speech did not proceed from the reflection that self-authorship requires. In any case, the law does not impose its teaching on a conscientious dissident. Viewed as punishing only lying, willfully blind, or unreflective purveyors of hate, the law teaches its lesson against abstract racial or cultural self-identification without violating any genuine right of self-authorship.

\section{External Protections}

Finely tuned laws prohibiting hate speech are one way in which governments legitimately promote the good intrinsic to culture by restricting the freedom of non-members. Kymlicka calls measures of this kind external protections, which he distinguishes from the internal restrictions that self-governing cultural communities might impose on their own members for the sake of cultural selfpreservation. This distinction is helpful, and I will adopt it. Kymlicka, however, treats external restrictions as permissible provided that they rectify cultural disadvantages and internal restrictions as impermissible. ${ }^{31}$ This dichotomy is too blunt, and so I will introduce further distinctions. Specifically, I will distinguish between external protections limiting libertarian rights to mobility, acquisition, and commercial speech, which are permissible, and those limiting egalitarian rights to self-authorship and self-rule, which are not; and I will distinguish between internal restrictions that are impermissible simply and those owed a duty of respect but not a duty of support. Here I deal with external protections against non-member individuals and consider what else governments may and may not do by way of protecting cultural communities through restricting the

Criminal Code, R.S.C. 1985, c. C-46, s. 319(3).

Multicultural Citizenship, supra note 2 at c. 8.

Vol. 8, No. 2

Review of Constitutional Studies 
freedom and opportunities of non-members. In the next section I deal with the limits of permissible accommodation of internal group practices.

Some external protections diminish the liberty of non-members without infringing their rights to liberty. Court decisions recognizing native land claims based on aboriginal title are of this kind; they simply recognize rights it would be wrong to invade. Other protections, however, limit liberty or opportunity, not in accordance with property or equal liberty, but just for the purpose of protecting the cultural practice or identity of a particular group. For example, a law might limit the liberty of motorists to drive through an orthodox Jewish neighbourhood on the Sabbath so as not to disturb prayers. ${ }^{32}$ A language law might limit the liberty to advertise one's wares or conduct one's business in the language of one's choice to the extent necessary to preserve the public presence of an endangered language in a province governed by the minority in a federation that speaks it; ${ }^{33}$ or it might prevent access by children of immigrants to public schools conducted in a continentally dominant language so as to immerse them in the language of the locally dominant culture. Further, a law might prohibit non-aboriginals from acquiring property on an aboriginal reserve in order to preserve the land base for native self-government; or from taking up residence on a reserve in order to ensure that aboriginals constitute a local majority of voters; or from voting or holding office if they marry band members and live on the reserve. Finally, public universities and professional schools may reject wellqualified non-aboriginal applicants in favour of less qualified aboriginal ones in order to provide strong leadership for aboriginal communities. Kymlicka justifies all such measures as necessary to equalize the cultural conditions for leading self-authored lives, but some can be justified in a way that respects cultures as intrinsic goods, while others cannot be justified at all.

The good in culture is qualified to override libertarian rights of mobility, acquisition, and speech (for example, commercial speech) that does not express a conception of the good life. This is so because, like these rights, cultures validate individual worth, but they do so as intentional structures of mutual recognition conferring solid worth, whereas libertarian rights emerge from implicit relations of mutual recognition between self-supporting agents whose worth then depends for its recognition, first, on self-interested strangers claiming authority to determine boundaries for themselves, and then on legally

32 Lior Horev, et al. v. Minister of Transportation, et al., reproduced in Lorraine Weinrib \& Tsvi Kahana, eds., Global Constitutionalism (Toronto: University of Toronto Faculty of Law, 1999) at 114.

33 Ford v. Quebec (A.G.), [1988] 2 S.C.R. 712.

2003

Revue d'études constitutionnelles 
untrammelled sovereigns. ${ }^{34}$ As examples of ethical life, cultures do better at what libertarian rights purport to do on their own, namely, realize the essential worth of individuals. Obviously, however, this justification for a cultural override of liberty rights implies a limitation. These rights can be legitimately overridden only for the sake of preserving cultures that are genuine examples of ethical life - that respect their members as free interpreters of the culture. Thus, it would be constitutionally wrong to limit anyone's liberty for the sake of preserving a culture that was internally repressive - say, the cult of a religious sect whose members are manipulated by a charismatic leader or a culture in which dissent from orthodoxy is punished. Such cultures are not certified as good by free members and so have no valid claim to public support.

Further, even if a way of life is worth preserving, limitations on libertarian rights can go no further than is necessary to protect it. That is, even though living cultures are better validators of individual worth than libertarian rights taken alone, the good in culture must still respect those rights, because cultures are not self-sufficient communities. As regimes of an indeterminate ethos, cultures do not respect morally autonomous agents. Libertarian rights too are part of a political life that is complete in dignity; for, when coupled with the egalitarian entitlements that complement them, they embody the final worth of autonomous agents and so lay down objective conditions for the reconciliation of political obligation and individual autonomy within a self-sufficient ethical life. So liberty rights maintain their force even in deferring to the good in culture. In positive constitutional law, the mutual deference of constitutional goods and libertarian rights is reflected in the doctrine of minimal impairment. Thus, in Ford $v$. Quebec, ${ }^{35}$ the Supreme Court of Canada struck down Quebec's commercial sign law because, in banning all languages other than French, it went further than was necessary to protect the public presence of the French language in Quebec; and in Lior Horev v. Minister of Transportation ${ }^{36}$ the Israeli Supreme Court fashioned a solution to the conflict between secular motorists and the orthodox Jews of Bar Ilan Street by prohibiting traffic only during the hours of Sabbath prayer. What appears on the surface as a pragmatic balancing of interests is really an intuitive grasp of the interconnected system of elements making up the self-sufficient political community.

34

For the despotic outcome of libertarian constitutionalism, see I. Kant, The Metaphysics of Morals, trans. by M. Gregor (Cambridge: Cambridge University Press, 1991) at 125: "The legislative authority can belong only to the united will of the people. For since all Right is to proceed from it, it cannot do anyone wrong by its law."

35 Supra note 33.

36 Supra note 32.

Vol. 8, No. 2 Review of Constitutional Studies 
If, however, libertarian rights of mobility, acquisition, and commercial speech yield to the good in culture, egalitarian rights of self-authorship and self-rule (provided they are consistent with the self-sufficient life as a whole, as hate speech is not) do not. This is so because the political community differs from the cultural community precisely in being a form of ethical life that the morally autonomous individual, who is already incipiently recognized in culture but whose development is arrested there, will freely endorse as sufficient for its dignity. Because cultural communities (insofar as they are good) themselves value free interpretive agency but (as resting on the authority of ethos) make no room for the free-thinking self, the conditions of self-authorship and self-rule are higher in the order of constitutional goods than given ways of life. They stand to culture as the self-sufficient community stands to partial communities or as the fully developed ethical life stands to embryonic ethical life. This means that it is unconstitutional under an inclusive conception of public reason to deny voting rights to non-aboriginal residents of a reserve (though it would be permissible to deny them residency), or to subordinate the freedom of religious conscience (in the matter of dress, for example) to the cultural identity of the majority, or to use public education and naturalization law to inculcate a particular cultural ethos (though it would be permissible to provide public education to the self-sufficient life only in the majority language), or to institute (even temporarily) reverse discrimination policies favouring aboriginal applicants, though other forms of affirmative action are not only permissible but required. Cultures are good, but these ways of protecting them are not. Indeed, they are incoherent. For if cultures are protected at the expense of self-authorship and self-government rights, then they are also protected at the expense of the complete ethical life within which they appear as constituent goods worthy of even-handed public support. Such protections now appear as one-sided assertions of ethos against "liberalism," where ethos must appear as illiberal and so as having no claim to support from the liberal state.

\section{ACCOMMODATION AND ITS LIMITS}

Fostering the common good in cultures not only requires protecting vulnerable ways of life from the potentially destructive consequences of nonadherents' untrammelled liberty; it also requires accommodating their distinctiveness, whether vulnerable or not, in the process of governing under a public conception of justice. Once cultures are seen as grounds of individual worth embodying a liberal good, policies aimed at assimilating them to the culture of the majority or that have assimilation as their probable effect are unconstitutional under the inclusive conception of public reason. Such policies tend to destroy the good of culture for some in order to enhance it for others. They remove for a minority, while strengthening for the majority, one of the

2003

Revue d'études constitutionnelles 
stable grounds of individual dignity. It is not that assimilationist policies violate a norm of aloof neutrality toward cultural contents, as would be the case if cultural membership were simply a life-style choice or even a primary good. It is rather that, because cultural membership is an intrinsic liberal good, such policies now violate a positive duty on government of even-handed support. Multicultural accommodation is now a constitutional necessity. ${ }^{37}$

Naturally, no single method of accommodation is uniquely mandated. Accommodation of differences may take different forms depending on whether the culture is carried by an aboriginal people with an historical claim to a territory, or by one of several co-original national or religious groups, or by the descendants of an immigrant population. Where a culture is actualized by a native people with aboriginal title to land (and that wishes to be part of a larger political community), public accommodation of its distinctiveness will take the form of deference to the territorial jurisdiction of the traditional self-governing bodies of that people, including the courts that interpret the nation's ethos; where a culture is carried by one of several co-original peoples, it will usually take the form of a federal structure of government giving that people its own regional government (if the group is concentrated in a geographic area) or jurisdictional autonomy (if it is geographically dispersed) with power over matters affecting the preservation of its culture; and where the culture is borne by an ethnic group descended from immigrants, accommodation will typically involve exemptions from general laws and public subsidies of cultural activities. ${ }^{38}$ Thus, the duty to accommodate may itself be adjusted to the contingencies of a political community's history and circumstances.

\section{A. Reconciling Accommodation with Legitimate Constraint: The Alternatives So Far}

The difficult problem raised by the duty to accommodate cultural difference can be formulated thus: what are the proper limits of accommodation under a liberal constitution, and how can these limits be imposed on parochial cultures without dissolving public reason into Western liberal ethos? As Shachar and others have pointed out, accommodating cultural difference can, if not constrained in some way, expose members of the culture - particularly women - to practices that violate their agency rights under the libertarian constitution

37 Thus, s. 27 of the Canadian Charter of Rights and Freedoms, Part I of the Constitution Act, 1982, being Schedule B to the Canada Act 1982 (U.K.), 1982, c. 11, directs judges to interpret the Charter so as to preserve and enhance the multicultural heritage of Canadians.

38 See e.g. Yoder v. Wisconsin, supra note 13.

Vol. 8, No. 2

Review of Constitutional Studies 
and their citizenship rights under the egalitarian constitution. We will see examples of this in a moment. Yet constraining these internal practices must be justified in a way that can win the assent of those who view all living cultures as intrinsically and equally good, or else the constraints will appear as the external impositions of an alien culture. What we want to avoid is a situation where constraints on internal practices in the name of liberty and autonomy appear to the members of traditional cultures as reflecting the values of an individualistic and autonomy-loving culture imposed on cultures for which autonomy is less important than belonging. Each of the constituent conceptions of liberal public reason (libertarian, egalitarian, and communitarian) has its own way of dealing with this problem, and each is in its own way inadequate.

For libertarianism, the possibility of illiberal cultural practices is an argument against accommodation per se and for supporting cultural communities only indirectly through protecting the equal right of all agents to the freedom of religion and association. In that way, it is said, the liberal state lends support to cultures that can win adherents to its ways without abandoning their members to abusive or discriminatory internal practices or to oppressive group hierarchies. ${ }^{39}$ There is, of course, an assumption implicit in this view that the dying out of a culture reflects its lack of value for individuals and that there is, therefore, no more point to supporting a moribund culture than there is to propping up an insolvent firm. This assumption is cousin to the view that goods the market won't support because they are not widely desired are not goods at all; but it is more naïve, for it insensitively ignores the pressures to assimilate placed on people who value their culture both by official policy and by the career demands faced by individuals seeking to live out their view of the good. There is, moreover, yet another parallel between libertarianism's economic and cultural policies of laissez-faire. Just as the former abandons the economically weak to their capitalist lords, so does the latter leave vulnerable members of cultures to the power hierarchies within them insofar as they choose not to renounce a deep source of personal significance in favour of the rights of denaturalized "man". That is to say, leaving cultures to a wholly autonomous sphere of private choice means the state's forgoing any leverage with which to promote changes in what goes on within them. ${ }^{40}$

39

For a version of this argument from a "moderate communitarian," see Allen E. Buchanan, "Assessing the Communitarian Critique of Liberalism" (1989) 99 Ethics 852 at 862-63.

40 Shachar adduces the example of the agunah or "anchored wife" in Jewish law, who may be kept from remarrying by a husband who arbitrarily refuses to grant a bill of divorce. Where cultures are not integrated into the public domain, unofficial law of this kind is shielded from scrutiny; see Multicultural Jurisdictions, supra note 4 at 57-60.

2003

Revue d'études constitutionnelles 
Beyond these problems, however, the libertarian posture toward cultural diversity exposes the liberal state to powerful critiques of its legitimacy from two directions. First, non-accommodation makes liberalism (insofar as it is identified with libertarianism) acquiescent in both the intentional and natural assimilation of cultural minorities into the culture of the majority and so makes liberal public reason an unwitting ally of the dominant ethos. Requiring a Jew or Muslim to close his shop on the Lord's Day violates no libertarian right of inward belief or freedom of association; nor does requiring an Amish youth to attend high school until age sixteen. Second, libertarian non-accommodation makes liberal public reason look like liberal ethos. This is so because, in viewing traditional ways of life as subjective individual choices, libertarianism can protect individuals against the rights violations of their own cultures only by asserting the rights of atomistic agents against those who see their agency as embedded in cultural ways of life. Thus, libertarianism's constraints cannot appear legitimate to those for whom culture is an intrinsic good.

Nor, as we have seen, can those of egalitarian liberalism. In contrast to libertarianism, egalitarian liberalism accommodates cultural difference for the sake of equalizing opportunities for leading self-authored lives. Yet, because it shares the atomistic premises of libertarianism, egalitarianism too sees traditional ways of life as subjective choices it would be unfair to subsidize publicly. Thus, egalitarianism accommodates only something called the cultural structure viewed as a context of choice; it defers to no determinate set of practices or way of life. ${ }^{41}$ Nonetheless, it expects these ways of life to defer to it. Egalitarianism holds all cultural practices answerable to the norm of equal self-authorship that justifies support for the cultural structure. Thus, while external protections that equalize opportunities for self-authorship across cultures are permissible, restrictions of self-authorship within cultures are not. In this way, egalitarianism reconciles a duty to accommodate with strong constraints on internal practices, but it does not reconcile constraint with legitimacy. For it too demands that the viewpoint for which agency is embedded in intrinsically good ways of life unilaterally yield to that for which individuals are sovereign choosers of their ends and cultures only instruments of choice. As a consequence, the enforcement of egalitarian constraints against self-governing cultural communities appears as the interference of an individualistic liberal culture into the internal affairs of a non-individualistic one. Since this interference cannot be justified on neutral grounds, egalitarianism ends up with constraints that are strong in theory and non-existent in practice. Kymlicka, for

41 In Multicultural Citizenship, supra note 2 at 76, the term cultural structure becomes "societal culture," which involves a common language and common institutions.

Vol. 8, No. 2 Review of Constitutional Studies 
example, insists on liberalism's normative authority to call illiberal internal practices wrong but counsels against the practical enforcement (through judicial review) of liberal norms against cultures that violate the rights of their members. This, he says, would be analogous to one sovereign state's interfering in the internal affairs of another. ${ }^{42}$

Communitarianism, by contrast, reconciles accommodation with legitimate constraints, but the constraints are weak. The communitarian constitution views each living culture as an ethical life in which individual agents recognize the authority of an ethos that reciprocally recognizes the free interpretive agency of individuals. Insofar as they conform to this structure, living cultures are certified as good by free agents, and their goodness commands respect. The corollary of this, however, is that cultures command respect only insofar as they are confirmed as good by free agents. Thus, cultures that coerce belief or that impose severe burdens on the freedom to leave the group may be interfered with in the name of public reason conceived as the universal form of ethical life. Such interferences are legitimate, and can appear so to the perspective that regards all cultures as equally and intrinsically good, because they seek to constrain group practices by a norm internal to the goodness of culture itself. Respect is shown cultures that are freely respected by their members and withheld from those that are not. Yet these constraints are fairly weak. As long as members are free to leave the group, practices that violate the egalitarian principle (say, by subordinating women to their husbands or by denying them an equal opportunity to pursue satisfying careers or the right to vote in self-governing bodies) or that deviate from the ways in which sexuality is integrated into stable relationships of mutual respect (for example, polygamous practices) are as valuable in the sight of public reason as egalitarian practices. Proscribing them for the sake of equality is interfering in the name, not of public reason, but of liberal ethos. Thus, each living ethos commands the respect of public reason and the tolerance of cultures whose ways are different. ${ }^{43}$

42 Ibid. at 158-72. Barry, by contrast, would enforce liberal egalitarian norms on the theory that liberalism is internally universalistic; see supra note 1 at 138 . But he offers no legitimation argument for enforcing liberal universalism that members of traditional cultures could accept. Indeed, he seems quite unconcerned by the legitimacy problem, resting content with asserting liberal egalitarian criteria of legitimacy (viz. neutral respect for conceptions of the good) against opposing conceptions (and then excommunicating as liberals those whose liberal sentiments make them uncomfortable about imposing a particularistic conception of legitimacy). See generally at 131-54.

43 For representative statements see Chandran Kukathas, "Cultural Toleration," in Ian Shapiro \& Will Kymlicka, eds., Ethnicity and Group Rights (New York: New York University Press, 1997) 69; and Michael McDonald, "Should Communities Have Rights? Reflections on

\section{3}

Revue d'études constitutionnelles 
The foregoing survey of theoretical models seeking to harmonize respect for cultural diversity with the authority of public norms reveals an obvious lacuna. Missing is an approach that would reconcile the duty to accommodate cultural difference with strong constraints on internal practices that can be accepted as legitimate from the standpoint that regards all living cultures as intrinsically and equally good (and that can therefore be enforced through judicial review). I do not say "that can be accepted as legitimate from the internal point of view of each culture." As we saw, such a criterion for the legitimacy of constraint is unreasonably demanding, for it makes the subjective point of view of each culture the arbiter of what is to count as a valid constraint on its practices. This would not be a reasonable test for the legitimacy of constraints on individual conduct, nor is it one for cultures. Such a test makes sense only from a position of cultural relativism, which, since it recognizes no external moral restraints on nations, has nothing to say against wars of cultural aggression and imperialism. That cultures are inherently worthy of respect is a proposition that flows, not from cultural relativism, but from a conception of public reason according to which all living cultures are instrinsically and equally good. Strong constraints on internal practices are legitimate if they could be assented to by those who take this philosophic position.

The rest of this essay seeks to supply the missing alternative. Before we begin, however, we need a rough map of the terrain. In general, the phenomena we are concerned with are cultural practices that violate the agency and citizenship rights that members enjoy under the liberal constitution. The question for discussion is whether and how the norms of that constitution may legitimately be applied to such practices so as to circumscribe a duty to accommodate cultural differences. But what cultural practices come into conflict with what liberal norms?

\section{B. Culture vs. Liberalism: A Taxonomy}

We can distinguish at least three types of collision between cultural practices and liberal constitutional norms. One type involves practices that coerce the individual's allegiance or involvement, either by punishing the expression of heterodox beliefs or by commanding demonstrations of loyalty or by direct

Liberal Individualism” (1991) 4 Can. J. L. \& Jur. 217.

Vol. 8, No. 2

Review of Constitutional Studies 
violations of bodily integrity. Cases of compulsory flag-saluting ${ }^{44}$ illustrate this type, as does the British Columbia case of Thomas v. Norris. ${ }^{45}$ Thomas, a member of the Coast Salish Nation living off the reserve, was abducted, battered, and wrongfully confined for four days by several other members of his band as part of a ritual initiation into a traditional tribal dance. During his confinement, Thomas was deprived of all nourishment but water, and was repeatedly prodded, bitten, and whipped by his captors, all with a view to inducing a "vision experience" from which, according to tradition, would issue his "song". Thomas, who at no time consented to the initiation, sued the defendants for assault, battery, and false imprisonment. The defendants claimed that the initiation ceremony was an ancient practice integral to native life and that it therefore fell within the aboriginal rights recognized by section 35(1) of Canada's Constitution Act, $1982 .{ }^{46}$ The court disagreed, saying that, even had an ancestral practice been proved, no custom involving "force, assault, injury, and confinement" could be an aboriginal right under the constitution.

Another type of collision involves cultural practices that violate a member's equality rights under the liberal constitution - rights to equal concern for selfauthorship and self-rule. The case of Santa Clara Pueblo v. Martinez ${ }^{47}$ is an example of this type. There, Ms. Martinez sought an injunction against the enforcement of a tribal ordinance denying membership in the tribe, together with the residence and inheritance rights that membership entailed, to children of female members who marry outside the tribe. No such burdens on intermarriage applied to male members. Martinez argued that the ordinance violated her right under the Indian Civil Rights Act, which applied to Indian self-government, to the equal protection of the laws. The United States Supreme Court ruled against her, arguing that, in the Indian Civil Rights Act, Congress had modified constitutional protections for the individual Indian in deference to tribal selfgovernment and cultural autonomy, leaving federal courts with jurisdiction only

44 See Minersville School District v. Gobitis, 310 U.S. 586 (1940), where the U.S. Supreme Court upheld in the name of the "Nation's fellowship" public school rules mandating flagsaluting against a freedom of religion challenge by a Jehovah's Witness. Justice Frankfurter wrote: "The ultimate foundation of a free society is the binding tie of cohesive sentiment. Such a sentiment is fostered by all those agencies of the mind and spirit which may serve to gather up the traditions of a people, transmit them from generation to generation, and thereby create that continuity of a treasured common life which constitutes a civilization" (at 596). The Court reversed itself in West Virginia State Board of Education v. Barnette, 319 U.S. 624 (1943).

45 [1992] 2 C.N.L.R. 139 (B.C. S.C.).

46 See R. v. Sparrow, [1990] 1 S.C.R. 1075.

47436 U.S. 49 (1978).

2003

Revue d'études constitutionnelles 
in cases of arbitrary arrest and imprisonment. The determination of tribal membership, the court said, was a matter central to cultural self-definition and survival; hence it was a matter best reserved to the tribes themselves, which had been left extensive powers to govern themselves according to their own traditions. The court did not consider whether, if the Indian Civil Rights Act did indeed dilute Bill of Rights protections in the case of Indian self-government, Congress had the constitutional authority to do this. It simply took for granted that Indian tribes, as "quasi-sovereign nations", were immune from constitutional constraints except insofar as Congress chose to modify that immunity - a doctrine that, in the guise of respect for Indian autonomy, actually re-enacts their subjugation.

A counterpoint to the Martinez case is Corbiere v. Canada (Minister of Indian and Northern Affairs) ${ }^{48}$ There, non-resident members of the Batchewana band challenged a section of the Canadian Indian Act that conferred band voting rights exclusively on band members resident on the reserve. Off-reserve members constituted a majority of the band and consisted largely of women who had been reinstated as members after Martinez-type legislation was declared to be in violation of the International Covenant on Civil and Political Rights. ${ }^{49}$ The Federal Court of Appeal found a violation of non-resident members' equality rights under the Charter, but, anticipating that there might be aboriginal rights based on ancient practice to discriminate among band members in the matter of voting privileges, it refused to invalidate the offending section generally, preferring a remedy that would apply only to the Batchewana band. Thus, the Court of Appeal was prepared to countenance the adjustment to ancient band practice of Charter equality rights with respect to self-rule. The Supreme Court, however, thought otherwise. Without saying whether it would ever entertain the idea of a band exemption from the Charter's equality rights, it struck out the offending provision generally and suspended its ruling so that the federal government and Indian bands might consult on new electoral arrangements that would recognize the (not necessarily equal) voting rights of non-residents. In this way, the Court fashioned a remedy that, by encouraging negotiations within the range of options approved by the Charter, tended to obviate the need for aboriginal claims to exemptions from the Charter's equality guarantees, at least with regard to voting.

48 [1999] 2 S.C.R. 203.

49 Sandra Lovelace v. Canada, Communication No. R.6/24 (29 December 1977), U.N. Doc. Supp. No. 40 No. $40($ A/36/40) at $166(1981)$.

Vol. 8 , No. 2

Review of Constitutional Studies 
Another contrast to Martinez is Dayton Christian Schools v. Ohio Civil Rights Commission. ${ }^{50}$ There, a teacher at a school requiring its faculty and parents to be "born again" Christians was told that her contract would not be renewed after she had become pregnant because of the school's belief that a mother with preschool age children should stay at home. She complained of sex discrimination to the Ohio Civil Rights Commission, which informed the school it could avoid legal action only by reinstating the complainant. The school brought an injunction against the Commission's proceedings, arguing that the Ohio Civil Rights Act prohibiting sex discrimination in employment violated its parents' and faculty's right to the free exercise of religion. The Court of Appeals agreed, but held that the state's interest in protecting individuals from sex discrimination was sufficiently compelling to justify the infringement. Nevertheless, the court ruled against reinstating the teacher, saying that this was an unnecessarily burdensome restriction of free exercise. The state's interest could be achieved less invasively by withdrawing tax exemptions and public services from a school that refused to comply with its laws promoting equal opportunity. Of course, the difference between Dayton and Martinez is that the latter was a case involving aboriginal self-government, whereas Dayton concerns a culture unprotected by powers of local governmental autonomy. We shall have to consider, however, whether that should make a difference to the jurisdiction of equality norms.

A third type of collision concerns cultural practices that violate liberal norms relating to the family. In particular, cultures may practise unconventional forms of marriage or engage in child-rearing practices (e.g. female circumcision or severe corporal discipline) harmful to the child's well-being and to its development as an independent moral agent. Some members of the Mormon Church, for instance, believe that polygamy is a divinely enjoined duty, breach of which is attended by eternal punishment. In Reynolds v. U.S. ${ }^{51}$ the accused, a Mormon who had been convicted under a Utah law that punished polygamy by up to five years in jail, argued that his constitutional right to the free exercise of religion entitled him to an exemption from the law. The Supreme Court disagreed, invoking the libertarian distinction between belief and action. Congress, the court said, was deprived by the First Amendment of all power over opinion, "but was left free to reach actions which were in violation of social duties or subversive of good order." 52 Polygamy is a practice of the latter sort, the court argued, because it is based on a "patriarchal principle" that has

\footnotetext{
$50 \quad 766$ F.2d 932 (1985).

5198 U.S. 145 (1878).

52 Ibid. at 164 .
}

2003

Revue d'études constitutionnelles 
despotism as its natural political consequence. Polygamy is a feature of "Asiatic and of African people" and "odious among the northern and western nations of Europe." 53

Of course, such explicitly ethnocentric arguments are odious to egalitarian liberals, for whom consensual polygamy is a life-style option that neutral respect for self-authorship must permit. Carens, for example, wonders why liberal democracies should prohibit polygamy at all given their commitment to the principle "that adults should normally be able to enter into whatever contracts or personal relationships they choose." ${ }^{\circ 4}$ Yet laws prohibiting polygamy can be defended under a liberal constitution as encouraging the integration of sexuality into relationships of mutual recognition conferring special worth on individuals. Requisite to objective confirmation of worth is that the commitment of each spouse be equal and reciprocal. If one spouse takes the other as an exclusive end, but the other remains free to take other spouses, then the first is not preserved as an end in devotion to the other; he or she becomes a means to the other's honour but receives no special honour in return. But then the servient spouse loses his or her qualification to give the dominant one the satisfying confirmation that can come only from an honoured end. If both are free to take other spouses, then there is an equality, to be sure, but one of non-recognition; again, no one receives validation for his or her special worth. Since these relationships fail to generate objective reality for worth-claims, they cannot receive the public authority's imprimatur as generating valid obligations. ${ }^{55}$ Thus only monogamy is civil marriage. Going through a form of marriage when one is already married debases the good of marriage (in the way that a counterfeit university degree debases the real one); hence it is properly proscribed under a penalty. The question, however, is whether the libidinal path to monogamy may be imposed coercively on communities of belief for which it is a path to damnation or whether such communities are entitled to an exemption.

The contest between ethos and liberalism also provides a new angle on Yoder v. Wisconsin ${ }^{56}$ already alluded to as a case illustrating egalitarianism's

53 Ibid. at 166.

54 Carens, supra note 3 at 155.

55 Thus, in Hyde v. Hyde and Woodmansee (1866), 1 P.\& D. 130, an English court refused to recognize a marriage between polygamy-practising Mormons in Utah because, the women not standing "upon the same level with the man under whose protection they live," the court "would be creating conjugal duties, not enforcing them, and furnishing remedies when there was no offence" (at 134, 135).

56 Supra note 13.

Vol. 8, No. 2 Review of Constitutional Studies 
expansion of the libertarian right to freedom of religion to include the freedom of conscientious action. In Yoder, an Amish sect claimed a constitutional right to an exemption from a state law requiring children to attend school until age sixteen because their religion teaches withdrawal from the values of the secularcapitalist world. Under the egalitarian constitution, the concern was whether Amish children schooled at home would be given an equal opportunity to succeed in fulfilling their life-ambitions, and the verdict was that an Amish education is well suited to that end. In the present context, however, the issue is whether an Amish child educated in a culturally sheltered environment will be raised to a consciousness of free agency so that, if he or she decides as a young adult to embrace the Amish way of life, he or she will have done so freely. Here, in other words, the concern is with brainwashing.

\section{Accommodation Under the Inclusive Conception}

The argument for reconciling constitutional accommodation of cultural diversity with strong but legitimate constraints on cultural practices is sensitive to the various types of collision we have surveyed. So let us deal with them one by one.

Practices that, like the Coast Salish rite in Thomas, fail to respect the free agency of adult members are disqualified as practices to which a duty to accommodate is owed. This is so, not because a libertarian norm condemns them, but because a norm internal to the goodness of culture does so. Cultures are intrinsically and equally good insofar as they are valued as grounds of individual worth by free agents who are reciprocally valued as vehicles of the culture's flourishing. That is to say, they are intrinsically good insofar as they exemplify the form of ethical life. Practices that coerce agents, punish dissent, and impose heavy burdens on the freedom to leave are not integral to cultures that exemplify this form, whether or not they are empirically integral to any particular culture. On the contrary, these practices are incongruous with the form of reciprocity in virtue of which cultures are freely certified as good by insiders and therefore worthy of respect by outsiders. Hence they are arbitrary exercises of power from the viewpoint of such cultures themselves and from the viewpoint for which all such cultures are equally good. It is not, as the court in Thomas concluded, that the right inhering in such practices is overridden by something weightier. It is that, regardless of their antiquity, no right inheres in such practices, because there is not the form of good in them that attracts a duty to accommodate. Thus, whatever other rights individuals possess under the liberal constitution meet no resistance in such practices. And the same could be said by a judge of a tribal court.

2003

Revue d'études constitutionnelles 
What of cultural practices that respect the free agency of members but fail to respect their claims to the things needed for equal self-authorship and self-rule? For egalitarian liberalism, such practices are owed no deference, for they are revisable choices in conflict with the principle of equal self-authorship that justifies support for language and heritage. In theory, therefore, the egalitarian principle meets no resistance from them, no matter how long-standing they are, though enforcement of the principle is, as we have seen, another question. Under the inclusive conception, however, the approach is more nuanced. Nonegalitarian practices are owed a duty of respect but not a duty of support. Respect is owed because these practices may cohere within a cultural ethos certified as good by free agents. Not all freely endorsed cultures, after all, value equal autonomy; in many, hierarchies are happily embraced by those whose opportunities are restricted. To the extent that non-egalitarian practices form part of a freely valued ethos, they evince the form of ethical life; hence they are liberal goods. That respect is owed, however, does not necessarily mean that non-egalitarian cultural practices set up insurmountable barriers to the intervention of egalitarian norms. It can also mean that their entitlement to respect is defeasible only by norms theoretically qualified to override it and only if the means chosen limit the right as little as possible. The question, therefore, is whether the egalitarian principle enjoining governments to equalize conditions for self-authorship and self-rule is qualified to override the duty to respect the good in free cultures. I'll return to this.

The duty to respect is not quite a duty to accommodate. A duty to accommodate includes a duty to support, promote, and foster, but this duty is not owed non-egalitarian cultures. This is so, not because egalitarian liberalism condemns their sexist practices, but because an ethical life sufficient for individual dignity encompasses cultures that are not self-sufficient, is concerned about its citizens who are members of the culture, and owes them a duty to encourage these cultures to reform themselves internally. Such a duty is inconsistent with a duty to support. Moreover, this judgment on non-egalitarian cultures is one that can be accepted from the standpoint of the agency-respecting culture itself. Cultures are good because and insofar as they are grounds of individual worth making room for individual agency. They are, however, insufficient grounds, because, while themselves acknowledging the need for individual endorsement, they make no room for the individual's reflective endorsement, because they claim authority simply as indeterminate ethos. They thus contain a potential that they themselves do not fulfill on their own. Like cultures, the political community is an ethical life in which citizens value the community as that which values their free thought and activity for the sake of its own actualization. But it is an ethical life whose goodness is now confirmed by morally independent and reflective agents because in it ethos has been replaced

Vol. 8 , No. 2

Review of Constitutional Studies 
by a public reason that is indwelling in all its constituent spheres: in living cultures, in the mutual respect of self-supporting property-owners, in the constructive self-legislation of ideal citizens, and finally in the actual loyalty of morally autonomous agents to the political community as to the self-sufficient basis of their dignity. Accordingly, non-egalitarian cultures are answerable to the judgment of the self-sufficient community not as to that of a foreign ethos but as to that of a life in which a potential encoded within them has fully developed and in which their claim to respect and support is itself vindicated. ${ }^{57}$

That the political community owes both a duty to respect non-egalitarian (but agency-respecting) cultures and a duty of concern for its citizen-members has the consequence that, in the case of these cultures, the duty to accommodate becomes a duty to educate. This duty cannot vary as between cultures that are carried by self-governing native peoples and those borne by groups with no territory to govern, for the duty is owed all citizens equally. How the duty is discharged, however, will no doubt vary along this dimension. Withholding public funding and services that are afforded other communities, as recommended by the court in Dayton Christian Schools,${ }^{58}$ is a way of instructing non-autochthonous groups, whereas negotiation with community leaders on selfgovernment arrangements is appropriate for native groups. The twin shoals to be avoided, however, are those represented by the approaches of the Ohio Civil Rights Commission in Dayton, on the one hand, and of the U.S. Supreme Court in Martinez, ${ }^{59}$ on the other. The coercive imposition of egalitarian norms when less intrusive means of effectuating them are available fails to respect the

57 Native people claim that their right of self-government is "inherent" rather than conferred by grant from the government of the settler population. By this they intend an historical claim to the effect that aboriginal people governed themselves before Europeans arrived and never relinquished their self-governing autonomy. This historical claim can be accepted without accepting the philosophical claim that aboriginal self-government is self-sufficient or self-standing. If the cultural community is not a self-sufficient life, then the governing agency of that culture is not a self-standing government. If the cultural community is embedded in the political life sufficient for dignity, then its self-government too is a constituent part of that larger life. Native self-government is no doubt inherent with respect to the government of Europeans. But government under a political life sufficient for individual dignity is no longer the government of Europeans. It is government under a conception of public reason that native communities can accept as the basis of their own claim to respect for cultural autonomy. The right to native self-government is philosophically embedded in that conception. Hence it is constrained by other requirements of the self-sufficient life.

58 Supra note 50.

59 Supra note 47.

2003

Revue d'études constitutionnelles 
intrinsic good in free cultures as well as their own capacities for internal reform and evolution. It thus makes liberal public reason look like atomistic liberal ethos. Paradoxically, the same result is achieved by the opposite approach taken in Martinez. By contemptuously treating self-governing aboriginal communities as lying outside the public reason of the constitution, the court in Martinez ensured that any legislative modification of that status would repeat the conquest by Europeans.

Suppose, however, that another case like Corbiere ${ }^{60}$ arises, only under different circumstances. Negotiations for electoral reform have failed with an Indian band that can demonstrate an aboriginal right based on ancestral practice to discriminate against non-residents or against women in voting. The band asserts this right as a shield against the intervention of the egalitarian norms of the liberal constitution. Such a case poses a head-on collision between the egalitarian principle and the duty to respect the good in free cultures. The resolution of the conflict, however, is already apparent. The egalitarian principle prevails, not because only cultural structures are owed respect, but because the right to self-rule is qualified to override the duty to respect the good in cultural practices. This is so because the right to self-rule belongs to a self-sufficient ethical life that can be endorsed as good by morally autonomous agents, whereas the good in ethos is a constituent part of that life, insufficient by itself for individual dignity. Ethos yields to equal autonomy, not as to a foreign and atomistic ethos, but as to the public ethical life in which the nascent autonomy of tradition-bound agents has fully matured and in which respect for ethos is securely established as one component of a life sufficient for dignity. Respect is shown both in the kind of justification required for an egalitarian override and in the constraints on the means permitted to implement it. The justification must be acceptable to someone for whom cultures are intrinsically good and not just instrumentally valuable for choosing personal life plans; while specific egalitarian reforms must (if possible) be negotiated rather than imposed and must tread as lightly as possible on long-standing cultural practices.

Finally, let us consider the limits on the duty to accommodate cultural practices relating to the family and how these might be justified consistently with public reason. I will deal specifically with the question of polygamy and with the child-rearing issue raised in Yoder.

Free cultures that practise polygamy are owed respect. However, the good in monogamous marriage is qualified to override the duty to respect a polygamous

$60 \quad$ Supra note 48.

Vol. 8, No. 2

Review of Constitutional Studies 
culture, because polygamy is contrary to the form of ethical life - the mutual and symmetrical recognition as ends of self and other - whose immanence in a culture is what entitles it to respect in the first place, while monogamy is an example of that form. Polygamous cultures are thus held only to a standard internal to the goodness of culture itself, by which standard polygamy is revealed as incongruous with any ethos whose adherents are equally valued interpreters thereof - that is, with any ethos endorsed as good by free members. Since this standard can be accepted by someone for whom all living cultures are equally good, the liberal depreciation of polygamy is now freed of the taint of ethnocentrism. Nevertheless, the right reposing in a free and dynamic cultural community demands that the instructive purpose of laws supporting monogamy be pursued with the least invasive means. This general directive might issue in two prescriptions, one fairly uncontroversial, the other more problematic.

Withholding public recognition from polygamous unions while exempting from punishment those for whom polygamy is a matter of religious conscience seems a sensible way of reconciling the instructive function of marriage law with respect for cultural diversity. Another way is to recognize de facto monogamous unions even if they were solemnized under a religious law that permits polygamy but to withold recognition from all unions subsequent to the first. According to our argument, the latter course would not be open, for marriage vows between persons whose understanding is that one or both is (are) free to take other spouses do not engender the validated worth-claims from which mutual obligations flow. So, not even potentially polygamous arrangements ought to be civilly recognized. ${ }^{61}$

An argument parallel to the one justifying monogamy to diverse cultures can be made regarding the rearing of children. The raising of children to moral independence is not a demand imposed by a liberal ethos of the atomistic individual. It is a parental duty going with the right each partner enjoys to the other's support; for the marital union in which the special worth of each is recognized is, as Hegel saw, embodied in the child, whose potential for agency is what makes it an especially fitting emblem of the intellectual aspect of the marriage bond. To develop this potential is to perfect the union in which the

61 English law now recognizes foreign marriages that are potentially polygamous in inception but that cease to be potentially polygamous by virtue of the English domicile of the husband. See Hussain v. Hussain, [1982] 3 All E.R. 369. This would seem to be a permissible variation, since in taking up domicile in a country that recognizes no marriage involving a person who is already married, the couple may be assumed to have undertaken the reciprocal commitment that was initially lacking.

2003

Revue d'études constitutionnelles 
reciprocal rights and obligations of the partners crystallize. Thus the parental duty to raise children to freedom flows from the same form of ethical life in marriage as underlies a free culture's right to respect. This duty is violated by practices, such as clitoridectomy and child-beating, that inflict permanent harm on children or that jeopardize their development toward moral independence. Because these practices close marriages to their end as worth-conferring relationships, they are inconsistent with the form of ethical life in marriage in virtue of which the lush variety of marriage and child-rearing customs compatible with this form are owed respect and support. Again, however, a selfreproducing culture's right to respect sets up a rule of minimal impairment of the culture's traditions. Certain types of female circumcision are harmlessly symbolic and so are mild forms of corporal discipline. ${ }^{62}$ Customs not in themselves harmful to children need not be proscribed simply because they are remnants of those that are. Moreover, in Yoder ${ }^{63}$ the Amish community was asking for an exemption from only the last two years of mandatory schooling; their children were in the hands of the public school system until age fourteen - plenty of time, one would think, to make their choice of baptism into the faith a free one.${ }^{64}$ Thus, even from the present perspective, the decision to uphold their free exercise claim seems sound.

\section{ACCOMMODATION AND DISESTABLISHMENT}

Under the libertarian and egalitarian constitutions taken alone, the liberal norm against the establishment of religion includes (besides an anti-theocratic, anti-coercive, and anti-preferential treatment principle) a neutrality principle enjoining government from endorsing the choice of religious belief over nonbelief. This follows from the libertarian aloofness toward what it regards as subjective conceptions of happiness and from the egalitarian duty of evenhanded concern for self-authored lives regardless of final ends, which it too takes to be subjective ${ }^{65}$ Thus, school prayers are forbidden even if voluntary and nondenominational, and aid to parochial schools is permitted only in the context of aid to education generally. Direct assistance to religious communities is out of the question, as is deference to the jurisdictional autonomy of religious courts in matters (such as family law) crucial to defining group membership.

62 See Carens, supra note 3 at $145-53$.

63 Supra note 13.

64 As Shachar observes; see supra note 4 at 98.

65 For a discussion of how a norm of even-handedness might structure a liberal policy toward cultures, see Carens, supra note 3 at $8-14$ and passim.

Vol. 8 , No. 2

Review of Constitutional Studies 
If truly an essential feature of liberalism, a principle of neutrality respecting belief and non-belief would put a severe crimp in a public duty to recognize and support cultural communities, for many of these communities are governed by a religious ethos. ${ }^{66}$ How could the United States accommodate the selfgovernment of the Pueblo Indians, whose governmental traditions are theocratic? How could India recognize the jurisdictional autonomy in certain matters of Muslim courts, which apply the law of the Qur'an? How could Israel delegate jurisdiction in matters pertaining to marriage and divorce to Jewish, Muslim, Christian, and Druze religious courts? Egalitarian liberalism avoids this problem with its distinction between cultural structure (which is supportable) and cultural character (which is not), but having spent much effort in debunking this dichotomy, we can hardly take refuge in it. Conceivably, we could simply collapse religion into cultural ethos, thus levelling the distinction between belief and non-belief, and leave religion as it sees itself — as a relationship to what is truly universal - outside the public domain. But to the non-believer, this will appear as a smuggling of religion into the state under a false cloak of neutral concern for culture; while from the believer's point of view, it will mean the failure to integrate religious communities as such into public reason, whose constraints on their practices will then appear as those of a secular and ungodly ethos.

But how to integrate them? The public duty to support cultural communities was justified on the basis that culture is an intrinsic and hence common good, part of a life sufficient for dignity. But the disagreement between believers and non-believers suggests that there is no common good in religion but only a particular conception of humanity's ultimate good, whose endorsement by the liberal state must fragment its public character. Accordingly, we need an argument showing why the anti-establishment norm of the liberal constitution ultimately does not include a neutrality principle prohibiting state support or accommodation of religion.

If the only public thing were the freedom to choose or the freedom reflectively to form and revise a conception of the good, then the specific choice of religious belief over that of non-belief would certainly be a private matter. The state's support of belief would then be an "entanglement" with the particular its universality could not survive. No doubt the state could sponsor a civil religion instilling the virtues supportive of a constitution ordered to respect for choice irrespective of the good chosen; but if public reason is choice or selfauthorship, the state cannot associate itself with, or appear to endorse, any

66 See Shachar, supra note 4 at c. 4.

2003

Revue d'études constitutionnelles 
conception of man's final end, including any conception of man's supernatural end. That is to say, it cannot associate itself with religious faith.

We know, however, that these conceptions of public reason are not exhaustive. Each has proved unstable when taken as the fundamental principle of constitutional order - has turned in its constitutional realization into an "authority" legally untrammelled by a duty to respect the independence of the subject. ${ }^{67}$ Nevertheless, they have not been cast aside. Rather, they are now constituent elements of an inclusive conception - instances of mutual recognition between self and other - in which that conception is confirmed as the ground of valid worth-claims through the spontaneous worth-seeking activity of the individual. They are thus chapters in a larger story - a story about preparing objective conditions for the mutual recognition of Law and Law's subjects, where those who rule in Law's name respect the worth-conferring relationships spontaneously formed by individuals, and where individuals recognize the authority of the political community as the self-sufficient ground of their inviolable worth.

Clearly, a state founded on that conception of public reason has nothing to fear from involvement with religion. Religions, after all, are cultures of a special kind. As ethoi reproduced by individual agents who submit to them without demanding their transparency to insight, they have the form of all cultures; and so their communities of belief, while grounds of individual dignity, are not selfsufficient for dignity. In their content, however, they themselves contain imaginative visions of the self-sufficient community and of the ultimate reconciliation of the idea of the universal with the singular individual. This gives the state a double reason for incorporating them. Like all cultural examples of ethical life, they are grounds of individual worth and so part of a life sufficient for dignity; but, in addition, as cultures themselves ordered to a vision of the self-sufficient community, they can, to the extent that their practices are not contrary to other parts of the constitution, contribute to educating citizens to the virtues needed to sustain that community - to the virtues connected with the obligations of spouse, parent, member of a cultural community, property-owner, job-holder, and citizen. Conversely, in recognizing religious communities for that purpose, the state makes possible their reciprocal recognition of the liberal state as ordered to a goal kindred to their own and so worthy of their allegiance. This makes liberal constraints on their practices seem less like the foreign

67 The argument for this claim lies outside the scope of this essay; I make it in a book in progress.

Vol. 8, No. 2

Review of Constitutional Studies 
impositions of a secular humanism and more like a model for spontaneous internal reforms.

Provided that support for the pedagogical services of religion is bestowed even-handedly to communities of all the major world-religions, none of the reasons for a religious neutrality principle apply to this sort of involvement. The neutrality principle is the anti-preferential treatment principle applied to the dispute between belief and non-belief. Here, however, the state does not favour the choice of belief over that of non-belief. It does not say that the religious way of life is nobler or more choiceworthy than a secular humanist way of life. Indeed, the state can be indifferent as to whether a citizen integrates himself into the institutions of the self-sufficient life guided by philosophy, by religion, or simply by the model of good parents and teachers, though it knows that philosophy is not for everyone, and especially not for children. In providing even-handed support to religious schools and communities, in adopting school prayers and non-denominational religious symbols (such as "in God we trust" or the reference to "the supremacy of God" in the preamble to the Canadian Constitution), the liberal state does not endorse religion over irreligion or encourage people to become religious; rather, it enlists the services, and encourages the allegiance, of those who are religious in promoting an end the non-believer can also embrace.

It may be objected, however, that the foregoing argument justifies at most state financial assistance to religious schools and organizations; it does not justify delegating (where there are historical reasons for doing so) jurisdictional autonomy to religious courts in matters crucial to group identity, for such a delegation, if it does not engage the reason for a neutrality principle, certainly seems to run afoul of the anti-theocratic principle. For it means state recognition and incorporation of a law whose authority is said to rest on a divine revelation.

However, this argument ignores the reason for an anti-theocratic principle. The liberal constitution includes such a principle, not because it is atheistic or even agnostic, but because a constitution ordered to an end given by a supernatural revelation, excluding as it does the self-rule of the free mind, necessarily becomes the despotism of those who interpret the revelation. Theocracy and constitutionalism are thus antithetical terms. However, the constitution ordered to the inclusive conception is open to the understanding of the free mind. That constitution makes room for the local autonomy of autochthonous cultures manifesting the form of ethical life; and it subjects that autonomy to constraint and oversight by courts applying the whole of liberal constitutional law, including the law of liberty and the law of equality, so that those who interpret the local ethos cannot exercise a despotic power. Under the

2003

Revue d'études constitutionnelles 
conditions of such a supervision, and assuming there are parallel civil institutions around marriage and divorce so that no one is forced to submit to the jurisdiction of religious law, does it matter whether those who voluntarily do submit believe that the law originated in a supernatural revelation or whether it has simply existed time out of mind? Would it matter to their validity if some people believed that the law against murder and theft originated on Mount Sinai?

\section{EPILOGUE}

I have argued that it is possible to reconcile a political duty to accommodate and promote cultural traditions with other, more familiar, liberal commitments. No doubt others have made arguments to a similar effect. What is perhaps different about this argument, however, is that it seeks to explain a liberal duty to recognize cultures without presupposing atomism, by which I mean the view that individual agents owe their worth to nothing beyond their own persons. The advantage of this feature becomes plain once we remember that theorizing a duty entails theorizing the conditions of that duty and that benefits thus come with reciprocal obligations. These obligations must be justified to those upon whom they fall, in this case to members of cultural communities. Such people are by definition not atomists, however, for a cultural devotee is precisely someone who derives personal significance from vivifying and transmitting a tradition; and because they are not atomists, cultural devotees are not members of a hypothetical cosmopolis either. Such people will therefore object to the imposition of obligations presupposing an atomistic ontology, obligations whose abstract universalism they will decry in the name of cultural pluralism and equality. By contrast, they will (this is a conceptual rather than a predictive "will") more readily accept an argument based on the idea of the self-sufficient community, for this idea completes and comprehends the idea of a living ethos, under whose banner cultural pluralists march against liberal cosmopolitans. Accordingly, a non-atomistic liberal argument for a duty to recognize cultures will be able to justify strong constraints on cultural practices acceptable to those for whom individual agency first gains its importance within communal frameworks. Such an argument will thus also be able to legitimate the practical enforcement of those constraints through, for example, judicial supervision of the self-governing bodies of cultural communities. It is, of course, a further question whether the argument from the self-sufficient community could ultimately be accepted by a liberal atomist. But that is a question for another day.

Vol. 8, No. 2

Review of Constitutional Studies 